\title{
Cholera in the Portuguese Region of Alto Minho in the Second Half of the Nineteenth Century: Epidemic Outbreaks, Treatment and Behaviours
}

\author{
Alexandra Esteves and Marta Lobo de Araújo
}

I

$\mathrm{n}$ the 19th century in result of the inherent advances of the industrializing process, the distances were shortened, distant regions became nearer and the circulation of people and goods through several parts of the globe was easier. The diseases also spread more quickly, assuming sometimes uncontrollable proportions, not only by land, but also by sea, through boats that, in addition of transporting people and goods, also served as means of transmission of epidemics into different countries and continents.

Along the 19th century cholera ${ }^{1}$ was one of the diseases that, both on land or by the sea, reached several areas of the European continent, causing a strong impact in the western civilization, not only in demographic and economical level, but also in social and cultural ones.

The disruptions caused by the illness, aggravated by the incompetence initially revealed by the authorities to avoid and fight this pathology, contributed to the appearance of not much coherent and even imaginative explanations and theories, in the desperate attempt of finding justification and solution for an evil that was affecting all, direct or indirectly. As an example, in 1866, in the sequence of the

1 Cholera is a disease caused by the so called Vibrio Cholerae, an agent transmittable through the water and from contaminated foods, or through the straight contact with contaminated individuals. Consult Ponce Herrero, Gabino. "Él Cólera en Alpera y Bonete. Siglo XIX.", Revista de Estúdios Albacetenses, n. ${ }^{\circ}$ 13, 1984, pp. 53-72. Asian cholera was known since old times, having references to this disease in Hindu books. See Lemos, Maximiano, História da Medicina em Portugal. Doutrinas e Instituiçôes, vol. I, Lisboa, D. Quixote, 1991, pp. 230-233. The first european references done on cholera were advanced by Gaspar Correia, in his work Lendas da India, in 1543 and, by Garcia da Orta, in 1563, which analyzed the disease from the medical point of view. On this subject see Cunha, Fanny Font Xavier da, "Evolução histórica da ciência médica e política patrimonial", Cadernos de Cultura. Medicina na Beira Interior da Pré-História ao Século XX, n. ${ }^{\circ}$ 16, pp. 67-72 and Ferreira, F. A. Gonçalves. História da Saúde e dos Serviços de Saúde em Portugal, Lisboa, Fundação Calouste Gulbenkian, 1990, p. 179. 
epidemic outbreak of cholera, which emerged in Portugal in 1865, the newspaper $O$ Vianense, published an article of the Gazette de France, where it is revealed the discovery of cholera by a doctor, who stated the idea that the origins of the Asiancholera were connected with the emission of poisonous gases freed by the bodies that, thousands of years ago were burnt in India. These gases were concentrated in the sky of the tropics, lifted to the most elevated regions of the atmosphere during the day, but after the sunset, they descended to the inferior regions, in order to being mixed with the water and the food, penetrating the lungs through breathing. When this poisonous gas was introduced into body, it caused the very own symptoms of cholera, as dysentery, vomiting and cramps. ${ }^{2}$

This theory met the normally accepted idea, until the discovery of the bacterial agents responsible for the infection, in which the infectious diseases were caused by miasmas, in other words, invisible substances emanated from organic materials in decomposition. ${ }^{3}$

Initially, the ignorance of the causes and ways of transmission of cholera made believe that the yellow fever, cholera, malaria and typhoid were not more than the same disease, but with different symptoms. ${ }^{4}$ These mistakes were resolved when Robert Koch, in 1883, discovered the bacillus of cholera.

Original from the delta of the Ganges, in India, the cholera assumed, for the first time, epidemic proportions in an outbreak that took place in the period between 1817 and 1823, having reached, in a first phase, China, Oceania, the Philippines and Japan, reaching, subsequently, Asia Minor and Egypt. A second outbreak took place between 1826 and 1837, with its origin again in the delta of the Ganges, having spread for the first time to Western Europe transported by soldiers and populations. From this point there were different epidemics of cholera throughout Europe and they devastated several regions. So, with bigger or less amplitude, a third outbreak happened between 1841 and 1862, a fourth between 1864 and 1875, and a fifth between 1882 and 1896, and yet to mention an epidemic of cholera that appeared in $1899 .^{5}$ Cholera reaches Portugal in $1832 .{ }^{6}$ The disease may have been

2 O Vianense, n.o 1306, 27 de Novembro de 1866.

3 Tally Ujvari, Stefan Cunha, A História e suas Epidemias. A convivência do homem com os microrganismos, Rio de Janeiro (Editora Senac Rio, 2003), pp. 153-157.

4 See Jiménez, Juab Bta Mateos. "Nacimiento de la Sanidad Internacional" Revista Española de Salud Pública, vol. 80, (2006), p. 654.

5 On several outbreaks of cholera consult Svobodný, Petr, "The Health of the Population and Health Policy in 19th century Bohemia: The Case of Asiatic Cholera (1830s-1900s)", in Abreu, Laurinda (Ed.), European Health and Social Welfare Policies (Compostela Group of Universities and the PhoenixTN, European Thematic Network on Health and Social Welfare Policies, 2004), pp. 200-215.

6 To point out that the date is not generally agreed, so, in the opinion of some authors, the cholera invaded Portugal earlier, more precisely in 1826. Viegas, Valentino; Frada, João; Miguel, José Pereira. A Direcção-Geral de Saúde. Notas Históricas (Lisboa, 2006), p. 7. 
carried to Portugal, by ships from the city of Ostende, in Belgium, that were heading to the city of Oporto in aid of the liberal armies. Quickly, it was spread throughout the North of the country. At this time, the country was plunged in a civil war, which opposed the liberal forces to the absolutists. After reaching the city of Oporto, cholera spread throughout the country, causing a total of 40.000 victims.'

However, this first outbreak did not reach any of the councils of the county of Viana do Castelo, located in Alto Minho, a region in the North of Portugal, but it affected several regions of the country, with particular severity Lisbon, where the victims' number reached the $13000 .^{8}$

The aim of our analysis consists in evaluating the impact that the epidemics of cholera caused in Alto Minho, region composed by the councils of Arcos de Valdevez, Caminha, Castro Laboreiro, Paredes de Coura, Melgaço, Monção, Ponte da Barca, Ponte de Lima, Viana do Castelo, Vila Nova de Cerveira e Valadares. This was an essentially agricultural region, where a great part of people were dedicated to agriculture and had the land as their main source of subsistence. Region where the needy classes had a poor food diet, subjected to the cereal crises, whose houses did not have the cleaning and salubrity conditions and the habits of personal hygiene were insufficiently implemented. This scenery was contributing for the appearance of diseases between the poorest, that could acquire an endemic aspect, originating epidemics that placed this region in fear.

After this first outbreak, measures and operating dispositions were carried out, in order to stop the entrance of cholera in Portugal, as well as other epidemics. In 1837, it was created the Public Health Council, working in the dependence of the Ministry of the Kingdom, to supervise all the aspects that were connected with health. With the same target the delegate's and sub delegate's posts were created for the Public Health Council, working in all the counties and councils, and for each parish the post of leader of health was created, which would be fulfilled by the regedor. ${ }^{9}$ These changes, unleashed by Passos Manuel altered in a significant way the concept of health in Portugal. Without neglecting the cure, the priority was centered in the prevention of the disease, as you can notice through the importance attributed to the inspection actions that were carried out in potentially unhealthy

7 On the advancements of cholera in national territory read Roque, João Lourenço, "Epidemias no distrito de Coimbra no século XIX (1830-1870), in Revista Portuguesa de História, 34, (2000), pp. 22-25.

8 Cholera reaches Portugal in 1832 transported by ships originating from the Belgian city of Ostende, which were addressing to the city of Oporto. Quickly the disease spread to all the north of the country. Read Cunha, Fanny Font Xavier da, "Evolução histórica da ciência médica e política patrimonial”, Cadernos de Cultura, p. 68.

9 Regedor - Administrative authority of a parish. 
spaces, or by the recommendations given to the city halls to look after the cleaning of these places. ${ }^{10}$

In 1848/1849, cholera was devastating Europe again, which led the Portuguese authorities to take several prophylactic and preventive measures, not always well accepted by the local populations.

Only in the fiftieth decade of the eight hundreds, cholera will appear in the county of Viana do Castelo. Meantime, the administrative authorities were taking the proper precautions and putting into practice the directives drawn by the health delegate. At local level, they were looking for creating awareness in people of the importance of the personal hygiene, the cares to have with the food, with the cleaning of their houses and even with the moment of death. In terms of the public hygiene, one was advised for the cleaning of the streets and the public spaces, the inspection of places of sale of nourishing goods, and the cautions to have with the corpses' funerals. On the other hand, in spite of the creation of hospitals for cholera patients ${ }^{11}$, several structures of organizing and support were created, for instance the help commissions set up in all the council parishes belonging to the county of Viana do Castelo.

Although in the wrong way, the cholera's miasmatic origin was ruling, and it is certain that it contributed to important developments in terms of the individual and public hygiene. To this purpose, it assumed particular relevance the fact that the populations were starting to be aware of the filthy and unhealthy places that were making easy the propagation of infectious diseases. In 1856, in a local newspaper of Viana do Castelo, a reference is made to the existence in the city "of many deposits of filth", mentioning butchers, factories and places selling food goods, giving particular distinction to the square where fish was sold, so "it is nauseating the pestilential smell that there is breathed" ${ }^{12}$, and about the prison located in the centre of the city, which, was not being aired properly, "preserves a corrupt air." 13

It was feared that the entrance of cholera in the Alto Minho was going to be by the sea, through boats coming from the dirty ports and that were mooring in the ports of Viana do Castelo and Caminha, or still by river and land road, in result of the regular contacts with the neighbour Galiza. In fact, these fears of penetration of cholera through the frontier with that Spanish province were based due to the cir-

10 On this subject consult Viegas, Valentino; Frada, João; Miguel, José Pereira. $A$ Direcção-Geral de Saúde. Notas Históricas, pp. 9-15.

11 Esteves, Alexandra, Assistência às vítimas de cólera no Alto Minho na primeira metade do século XIX. (in press).

12 Big cities, like, for example, London also were corrupted by the bad smells. George Gissing, in his work The Nether World, he tells this about the biggest European metropolis of that time: "the air is poisoned by the odor of lack of cleaning". See Charlot, Monica: Marx Roland (dir.), Londres, 1851-1901. A era vitoriana ou o triunfo das desigualdades (Lisboa, Terramar, 1995), p. 56.

13 Aurora do Lima, 27 de Maio de 1856, n. 65. 
culation of people between the two sides of the frontier, which has took the Portuguese authorities, to impose a sanitary cord, at the least suspicion of the presence of some cholera outbreak in Galiza,. However, this measure was not always understood and respected by the populations, especially by the poor, that needed to maintain the connections with that neighbor of the other side of the frontier to insure their survival, just like in the case of the fishermen of Caminha.

In $1853^{14}$ the cholera invaded Galiza. In December of the same year, in the village of Valença, belonging to the county of Viana do Castelo, a woman, who was known to have been in that Spanish province some days before, manifested the symptoms of the disease. Facing this first case, immediate measures were taken to avoid the propagation of the illness, cutting the communications with Galiza and isolating the house of the contaminated family. ${ }^{15}$

On the 3rd of January of 1854, the health delegate informed the civil governor of the county of Viana do Castelo of the non-existence of any case of cholera in Valença, as the situation was controlled in that district. ${ }^{16}$ However, he noticed the maintenance of the epidemic in the neighbour Galiza, underlining therefore the necessity of the maintenance of the sanitary cord and the cut of communications with that region. Bay the way it matters to say that the Galician authorities not always showed their collaboration in the combat of the disease, showing, some times, a certain resistance in admitting the existence of cholera in their territory. As a matter of fact, there were frequent complaints by the Portuguese heath authorities to the Civil Governor because of this behaviour and of the damages that it could cause in the public health. Such an attitude had to do, especially, with the negative impact that the sanitary measures imposed by the Portuguese were causing in their economy. Therefore it was necessary a very careful attendance by the Portuguese authorities of the sanitary situation of the neighbor Galiza.

The council administrator of Vila Nova de Cerveira knowing of the cases of cholera in the council of Valença, not only cuts communications with Spain, but also ordered that the relations with Valença should be restricted to guarantee the efficiency of the sanitary measures planted in his council. ${ }^{17} \mathrm{He}$ officiated to the Spanish authorities of Tuy and Vigo in order to obtain more information on the incidents of the illness in those places, but he didn't get any answer. In January of 1854, the same administrator informs the civil governor of the difficulty in maintaining the cuts of communication with the Galiza, because of the fishermen, therefore he found necessary the intervention of the military strength to enforce this

14 The Galiza had big outbreaks of cholera in 1833, 1853 e 1863. Simon Lorda e Rúa, Dominguez M., "Él cólera de 1885 en Ourense", Minius XIV, 2006, p. 270.

15 Historical archive of the Civil Government of Viana do Castelo (henceforth AHGCVC), received Correspondence of the health delegate, n. ${ }^{\circ}$ 1.13.6.10-1, not paginated.

16 Ibid.

17 Ibid. 
decision. He commanded the apprehension of the barges of the fishermen and placed policemen in the points of the river passage to make this measure possible. ${ }^{18}$ Also he asked the commander of the fourth military division, for the house of the government of the square of the town in order to establish a hospital there for the treatment of cholera patients, and he formulated a petition to the brotherhoods, in particular to their treasurers, in order to dispose an amount of their funds to help the poor patients, if cholera reached that district, which did not come to happen. ${ }^{19}$

The council administrator of Monção equally let know to the civil governor that the cholera persists in the Galician coast, presumably in result of the infection through an English boat, whose crew was presenting symptoms of cholera. Due to the geographical proximity, the communications were cut with Galiza, and it was proceeded with the organization of help commissions and according to the arrangements of the city hall, they took hygiene measurements, such as domiciliary visits to check the cleanliness and the cleaning of the houses, especially the poor ones, inspection of the consumable foods and of the places of sale and the cleaning of the public spaces of the town. ${ }^{20} \mathrm{~A}$ special preoccupation happened from the part of the authorities in installing and generalizing a set of practices of hygiene and prevention with the intention of safeguarding the public health. For that it was necessary to educate the populations, especially the poorest extracts, whose houses, shared very often with animals, were accumulating all types of filth and whose residences were favoring the appearance and the propagation of diseases.

The council administrator of Caminha, recognizing the importance of the cut of communications with Galiza, officiated to his homonym of La Guardia, asking him to obstruct the passage of people of that village to Caminha, in order to fulfill integrally the principle of cut of communications. ${ }^{21}$ However, since it will be shown further on, this administrator faced the difficulties and the resistances caused by the imposition of the cut of communications with the nearby region. Knowing that the port of Lugo was infected, this same authority, questioned the civil governor of the county of Viana do Castelo on the proceedings to take if infected ships moored in the port of Caminha. ${ }^{22}$ Such behavior demonstrates that the administrative authorities were still not properly informed on measures regarding the vessels originating from contaminated ports, and that might constitute one of the roads of propagation of cholera. The council administrator of Caminha also notices the shortage of the charities gathered by the help commissions in the different communities of the council, since they wouldn't serve for much, if cholera reaches that county, which

$\begin{array}{ll}18 & \text { Ibid. } \\ 19 & \text { Ibid. } \\ 20 & \text { Ibid. } \\ 21 & \text { Ibid. } \\ 22 & \text { Ibid. }\end{array}$ 
will happen in the next year, in $1855 .{ }^{23}$ This way the above-mentioned administrator was revealing some of the fragilities inherent to the measures extolled in the sense of avoiding the penetration of cholera.

In the beginning of January of 1854, the health delegate is invited by the Spanish authorities to participate in a commission of doctors and, according to superior orders, they should go through the different points of the Galician province to observe the cases of cholera that were happening there. This meeting had the participation of nine doctors, from Pontevedra, Redondela and Tui, and was headed by the Governor of the province. However, the health delegate of the county of Viana do Castelo refused to accept this invitation, due to the cut of communications that were still happening with Galiza. ${ }^{24}$

At the end of January 1854, the situation seemed stabilized. In a report sent to the Public Health Council, the delegate of public health was demonstrating to be informed of the sanitary situation in Galiza, saying, however, that, officially, he was informed of only one incident of cholera case in the city of Tuy, when later he knew that, in fact, there were forty three cases registered. This episode comes, at last, to corroborate the idea that the Galician authorities were omitting or distorting the real dimension of the problem, which was reinforced the necessity of maintaining the sanitary cord.

The cases of cholera that were felt in Valença, at the end of 1853, though sporadic and quickly controlled, led the sanitary and administrative authorities to be preoccupied and endow the councils with structures for the treatment of cholera patients, which is an example the construction in the fort of Novelhe, in Vila Nova de Cerveira, of an intern lazareto, ${ }^{26}$ which started functioning it the beginning of February 1854, destined not only for the patients of cholera, but also to provide lodging for individuals who for one reason or another should be subdued to a sort of quarantine. This institution would be endowed with a doctor, a pharmacist, two servants and an outdoor policeman. ${ }^{27}$

The county communities nearby Galiza were on alert and frightened by the possibility of penetration of cholera through the frontier. In March 1854, the council administrator of Ponte da Barca and the community regedor of Lindoso, knowing that cholera was developing gradually in Galician lands, a few légoas ${ }^{28}$ away, asked the help of the health delegate, in order to obstruct the entrance of the disease in their territory. The health delegate proceeded with the necessary diligence, and officially consulted a vice-deputy in Tui and the doctor in charge of the cases of cholera

23 Ibid.

24 Ibid.

25 Ibid.

26 Lazareto - Building for quarantines.

27 AHGCVC, received Correspondence of the health delegate, n. ${ }^{0}$ 1.13.6.10-1, not paginated.

28 Légoa - Ancient unit of itinerary measure, measuring five kilometers. 
on the side of the frontier, in order to certify themselves of the presence of the illness in the Galician region. As a response he obtained the confirmation that, in fact there were cases of the disease happening in the province of Ourense. ${ }^{29}$

The sanitary cord will be maintained during the next months, involving 30 to 40 policemen of the customs, 16 soldiers, and some police officers, that had the mission to guard the frontier from Caminha to Melgaço. ${ }^{30}$ However, it will not be enough to avoid the reappearance of the cholera evil, between 5 and 14 of May of 1854, in the council of Valença. Such situation happened after a market took place, in the city of Tuy, were inhabitants of the council of Valença had gone, not respecting the sanitary cord, later four individuals perished. ${ }^{31}$ Again, the entrance of the epidemic was registered through the border, which demanded the increase of the warnings regarding the neighbour Galiza, from where it was known beforehand, that it wouldn't be given any cooperation.

In the 9 of May 1854, after having the news of a propagating cholera outbreak in Valença, the city hall of Monção met the council administrator and the doctor of the party, in order to adopt immediate measures to obstruct the entrance and propagation of the cholera virus in the council. It was then decided to reestablish the cut of all communications with Galiza and to interrupt the contacts with Valença; it was determined the withdrawal of all boats at half a légoa of distance of the river Minho and the destruction of all the vessels that were not respecting this resolution; a hospital was created for the treatment of cholera patients, with the capacity to receive between 20 to 30 patients, benefiting from the financial support of the brotherhoods and of the Misericórdia of the village, especially in the support of goods for the patients and for the nurse's salary. ${ }^{32}$ The city hall compromised itself to deal with the other expenses. On the other hand, people coming from Galiza would remain for a determined time in a certain place, in a kind of quarantine, before coexisting with the remaining members of the community. ${ }^{33}$ Simultaneously, the administrative and sanitary authorities reiterate the importance of the cleaning of the public spaces and of the elimination of all the possible focuses of infection, as well as the necessity of improvement of the life conditions for the most in need, especially what concerns food and clothing, as these were the most fragile ones, they

29 AHGCVC, received Correspondence of the health delegate, n. ${ }^{\circ}$ 1.13.6.10-1, not paginated.

30 Telly Cyrne, Francisco, "A cólera-morbus no distrito de Viana do Castelo (Apontamentos)", Arquivo do Alto Minho, 4. ${ }^{\circ}$ vol. Tomos III e IV, (1955), p. 113.

31 Esteves, Alexandra, Assistência às vítimas de cólera no Alto Minho na primeira metade do século XIX. (in press).

32 Misericórdia - Lay brotherhoods that at the Council of Trent obtained the privilege of "immediate royal protection". These brotherhoods practiced the fourteen Works of charity and became the most important institutions of charity in Portugal.

33 AHGCVC, received Correspondence of the health delegate, n. ${ }^{\circ}$ 1.13.6.12.12, not paginated 
would be more exposed to get infectious diseases, that could be avoided by preventing them. ${ }^{34}$

In Caminha, the council administrator, after having been notified through a circular of the civil government of Viana do Castelo of the existence of cholera in Valença, he explains the preventive measures applied in his district, regarding, the interruption of the connections with Galiza, the realization of domiciliary visits, the checking of the cleanliness of the houses of the residents in the councils, and the creation of a hygienic commission composed by health professionals and a priest. To refer also that this commission asked the council administrator to notify the civil governor in order to get authorization so that the town of Caminha could spend money from their safes with the necessary investments in order to guard themselves properly, if the cholera emerges. ${ }^{35}$

In July 1854 , due to the rumors of the persistence of cholera in Galiza, ${ }^{36}$ the civil governor of Viana do Castelo put in charge the council administrator of Caminha in order to know the truthfulness of those rumors that were alluding to the presence of the disease in Pontevedra and Ourense. However, such information was contradicted by the vice-deputy of La Guardia, who guaranteed he would communicate any incident. ${ }^{37}$ Afterwards, by the end of August, several cases of cholera occurred.

In September of the same year, the health delegate of Viana do Castelo informed the civil governor that the cholera developed gradually in the province of Ourense, up to four légoas of distance from the frontier, though the vice-consul of Tui gave no knowledge of this event, considering that this neglected act would put in risk the public health in the county of Viana do Castelo. ${ }^{38}$ Also the council administrator of Vila Nova de Cerveira announced to the civil governor the existence of cases of the disease in Galiza. ${ }^{39}$

Regarding this situation, in September 1854, it is ordered to the council administrator of Melgaço to he shut down immediately all communications with Galiza, through the dry line, as the Galician frontier was considered dirty recurring for that to armed forces. At the same time, it is reiterated the importance of the help commissions that had to exist in all the villages. ${ }^{40}$

Facing the aggravation of the situation in Galiza, in September of the same year, the Public Health Council ordered the shutting down of communications with all of Spain, with the exception of the entrance of cattle by water and fish, through a

34 Ibid.

35 Ibid.

36 Ibid.

37 Ibid.

38 Ibid.

39 Ibid.

40 Ibid. 
fiscal point in each council, at the administrator's choice. ${ }^{41}$ The news from the province of Ourense, was not particularly encouraging, noticing the death, on the 15th September, of five individuals, and, the next day, other three deaths, in the above-mentioned province. ${ }^{42}$ The rumors of the existence of an outbreak of cholera in Spain intensified through people who were coming to the councils of the Alto Minho to treat business or were going to health-resorts in Monção.

In October 1854, the Health Council launches a new edict with measures that should be applied in all councils, to avoid the penetration and propagation of the cholera disease. In the council of Monção, all communications with Galiza were suspended, with the exception of the entrance of cattle by water and fish, according to the established by the Public Heath Council in the previous month. ${ }^{43}$ However, the administrator declares the embarrassment caused by the sanitary cord and the difficulty in preventing people from crossing the border, because many inhabitants of that council needed to move to Galician territory in order to guarantee their subsistence. ${ }^{44}$

The council administrator of Caminha, also noticed the difficulties in imposing a sanitary cord and in making sure of the cut of communications with Galiza, especially, due to the resistance of the inhabitants of the riverside community of Seixas and Lanhelas, very poor villages, that were living only from the fishermen's activity and to secure their subsistence continued to move from one side to the other of the frontier, through the river Minho. ${ }^{45}$ On the other hand, the imposition of measures of prevention and inspection demanded investments which neither the city hall nor the help commissions could carry out due to the lack of financial resources, because the council was being affected by a serious food crisis and people could offer nothing, as they had not enough for their survival. ${ }^{46}$

In November 1854, in the council of Monção, edicts were stuck with regulations from the police and municipal postures, in which the awareness of the populations was directed to the importance of the cleaning their own houses and shops of commerce, the prohibition of selling foods in bad condition and the beginning of the establishment of cutting all communications with Galiza. ${ }^{47}$

Also in Caminha, after the official knowledge that Galiza was infected with cholera-morbus, through the circular of October $1854^{48}$, as well as in the other councils belonging to the county of Viana do Castelo, the council of public health deter-
41 Ibid.
42 Ibid.
43 Ibid.
44 Ibid.
45 Ibid.
46 Ibid.
47 Ibid.
48 Ibid. 
mined that the following measures were put into practice: cut of communications with Galiza; sending the heat-resistant to the fort of Novelhe and, subsequently, handed to the public prosecution service; convocation of the help commissions to enter the service; elaborate the principles of the medical policy for the council; choosing the appropriated place for the establishment of the hospital for cholera patients; division of the council in sanitary counties; instructions to the regedores to announce the doctors any case of cholera that they knew of; the doctor should immediately go and meet the patient, in a rented mount, accompanied by a nurse; direct the stray and the discriminated people attacked by the disease to the hospital created for this act; daily sending, for each one of the doctors, to the city hall's doctor or surgeon, a report of the cases of cholera when they took place in the respective sanitary county; elaboration by the doctor or city hall surgeon, of a general report based on the partial reports sent by the counties doctors, and afterwards sent to the delegation of health of the county; realization of domiciliary visits by the doctor or surgeon of the party; ${ }^{49}$

In spite of the established alarm, the cholera did not reach the county of Viana do Castelo in 1854, but it was felt in the autumn of the next year, when it attacked with particular severity in Viana do Castelo, Caminha and, with less intensity, in Ponte de Lima. In the summer of 1855 , the authorities became aware that this evil was already affecting the nearby $\operatorname{cities}^{50}$, and therefore, became necessary to endow the county with the necessary ways to avoid its penetration, or, if that was not reached, try to reduce its effects. The cholera arrived again through Spain and North Africa. The measures then adopted were similar to those who had been ordered by the public health council in 1854, and that were based on the creation of determined structures, like, for example, hospitals for cholera patients and help commissions, and also the cleaning of the public and private spaces.

In the meantime, we can consider that, along the XIX century, the different epidemic outbreaks, not only of cholera, but also, for example, of the yellow fever, associated to new bourgeois values, like the importance of the bath and other intimate hygiene practices, and to a new medical mentality, had a strong impact in the development of the public and private hygiene. The water turned into an essential element for the cleaning of the streets, houses and bodies. The hygiene is not simply connected with the mere cleanliness or with demands of aesthetic order, but also with health. In order to guard himself from possible illnesses and diseases the individual should wash himself. ${ }^{51}$

We cannot categorically affirm that a generalized change of behaviours has happened. We presume what the hygienic and sanitary concerns were intensified espe-

49 Ibid.

50 Ibid.

51 On this subject consult Vigarello, Georges, $O$ limpo e o sujo. A higiene do corpo desde a Idade Média (Lisboa, Editorial Fragmentos, 1988), pp. 141-150. 
cially by the approximation of the epidemic outbreaks, though it is recognized, obviously, the importance of the cleaning of the public spaces and the necessity of instilling in the people private hygienic habits. ${ }^{52}$

In the summer of 1855 , facing a new sanitary crisis that was coming near the county of Viana do Castelo, the health delegate alerts for the necessity of putting an end, once and for all, to the burials inside the churches. ${ }^{53}$ The public authorities moved in order to adopt preventive measures to preserve the city's public health, like the visits to the pharmacies and to the points of sale of edible goods, as well as in fund raising to help the poor patients by the help commissions created in the parishes. $^{54}$

In spite of the measures taken, the cholera reaches the city of Viana do Castelo again, and at end of September, counted already 74 dead. In the same month, the disease reaches Caminha, registering, between October and November 158 cases, some of them mortal. ${ }^{55}$ The community of Seixas, also affected, had months before another epidemic, which had sacrificed 30 individuals. According to the health delegate, such a circumstance was connected with the fact of being a fishermen's community, very poor and without hygiene habits. ${ }^{56}$ On a national level, the outbreak of cholera felt in 1855 caused 8710 deaths. ${ }^{57}$

After this outbreak, which was felt in the Alto Minho between 1855 and 1856, the cholera will return to Portugal in 1865. At this time, in the county of Viana do Castelo there was already written press, which let the population know, sometimes in a dramatic way, the impact this illness was causing in different regions of Europe, presenting also medicines and home-made medicines that were considered miraculous to avoid or cure the disease. But, the newspapers started to be, especially, a way of denunciation and protest against the non-existence of a public hygiene policy in the city of Viana do Castelo, thought to be of primordial importance to avoid the explosion of infectious pathologies.

52 According to the teacher José Júlio Rodrigues, the city of Lisbon only woke up for the sanitary and hygienic concerns in vespers of new outbreak, after years of accumulating insalubrities and filth, where the presence of organic debris in the streets were still constant. Rodrigues, José Júlio. "Lisboa e o Cholera", Biblioteca do Povo e das Escolas, n. ${ }^{\circ} 88$, (1884), pp. 4-5.

53 AHGCVC, received Correspondence of the health delegate, n. ${ }^{\circ} 1.13 .6 .12-1$, not paginated. In the district of Coimbra, region in the center of Portugal, similar measures were equally taken in order to stop the development of cholera, like the suspension of market fairs, the inspection of food supplies, material and spiritual help, sending doctors and the installation of infirmaries and hospitals for patients with cholera. To be confirmed read Roque, João Lourenço, "Epidemias no distrito de Coimbra no século XIX (1830-1870)”, p. 81.

54 AHGCVC, received Correspondence of the health delegate, n. ${ }^{\circ}$ 1.13.6.12-7, not paginated.

55 Esteves, Alexandra, Assistência às vitimas de cólera no Alto Minho na primeira metade do século XIX. (in the press).

56 AHGCVC, received Correspondence of the health delegate, n. ${ }^{\circ}$ 1.13.6.12-1, not paginated.

57 See Cascão, Rui, "Demografia e sociedade" in Mattoso, José dir., História de Portugal, vol. V (Lisboa, Círculo de Leitores, 1993), p. 432. 
In August 1865, after the knowledge of several cases of cholera in Spain, it is ordered, again, the imposition of a sanitary cord with the nearby country. ${ }^{58}$ The public health council determines the establishment of measures to control the cholera: the cleaning of public spaces, the whitewashing of particular houses, removal of mud, rotten materials and of all the filth susceptible to be turning into infectious focuses, destruction of dunghills and deposits of filth water that are in the patios or in the back yards, and prohibition of circulation of dirty animals in the city. ${ }^{59}$

Meantime, the cholera is developing gradually in several regions of Europe, such as Turkey, Prussia, France, Russia, Italy, Austria, England and Spain. This news took the city council of the city of Viana do Castelo, in session on 26 of August of 1865 , to release 900.000 réis $^{60}$ destined to the built of preventive actions, especially in the neighborhoods of the suburbs of the city, where the most poor families were concentrated, as well as assuming the payment of medicines for the poor people attacked by the epidemic. ${ }^{61}$

In October 1865, the cholera reaches Portugal, provoking deaths in Elvas. According to the local newspaper $\mathrm{O}$ Vianense, its arrival in national territory was predicted a long time ago, because of the contacts maintained with the infected nations and since the public hygiene was too far behind. It considered essential the elimination of all the focuses of insalubrities, public and individual, that existed in the city of Viana do Castelo, as well as an effective inspection of the public cleanness. The same newspaper points out that it's not only necessary to clean the streets, but also to move the deposits of filth far from the villages and create a medical police who watches and supervises the foods exposed in the different posts of sale of the city. ${ }^{62}$

However, the press does not stop praising the action of the civil governor, whose initiative was crucial for the establishment of a set of measures of preventive character, soon after the knowledge that cholera was developing gradually in Alentejo. In August, this authority sent to all the councils administrators the instructions received from the health council, in order that they are distributed by the juntas de paróquia $^{63}$, regedores and doctors, and recommended to the city halls proper application of the municipal postures, namely what concerns the cleaning of the councils.

In October, the civil governor ordered to the councils administrators the application of the arrangements predicted in the decree of 3 rd January 1837, which were determining the announcement of the detected cases of cholera to the superior

58 O Vianense, 29 de Agosto de 1865, n. ${ }^{\circ} 1117$.

59 O Vianense, 7 de Setembro de 1865, n. ${ }^{\circ} 1121$.

60 Réis - Ancient monetary unit.

61 O Vianense, 9 de Setembro de 1865, n.o 1122.

62 O Vianense, 21 de Outubro de 1865, n. ${ }^{\circ} 1140$.

63 Paróquia -Part of the territory of a diocese trusted to the direction of a priest who has the name of "pároco", a parish priest. Parish. 
authorities in charge of the conservation of the public health. On the other hand, it was recommending, that the doctors send monthly a list of the treated patients to the health delegate, specifying the illnesses.

With permit of the same date, the county council authorized the city halls, juntas de paróquia and places of piety and kindness to come forward with the sums of which they could dispose for the development of preventive measures against cholera, or, if that was the case, for the treatment of the poor patients.

The Carmo`s Third Order hospital was mobilized to receive infected patients, and it was necessary to provide it with clothes, enxergas ${ }^{64}$, among other things. In October, the civil governor met the military forces parked in that city, the provider of the city's Santa Casa da Misericórdia, the superior of the Mental Hospital of Hampered of the Charity and the delegate of the heath council and the civil and military doctors of the city, to obtain support for the installation and functioning of a hospital for cholera patients and for the improvement of the medical services available in case of epidemic. At the time, the city had only 3 civil doctors for nine thousand inhabitants, fact that took the civil governor to look for support among the military doctors, asking them for help in case of epidemic. ${ }^{65}$

After the situation in Elvas was controlled, in January 1866 there is notice of some cases of cholera in Freixo de Espada à Cinta. However, in February 1866 the situation seems controlled, not being noticed any case in the Alto Minho region ${ }^{66}$.

Cholera and other epidemic outbreaks contributed so that in Portugal, and in the particular case of the Alto Minho, questions like medical policy, public and private hygiene were in the centre of the preoccupations and were discussed, not only by the administrative and sanitary authorities, but also by the general population. The newspaper is turned into a kind of a spokesperson of these problems, denouncing the deficiencies and the lacks of a very incipient public health system. The Vianense, on 23rd August 1866, was denouncing this situation, telling that, from the biggest city to the small parishes, were not noticed any tracks of medical police officer and public hygiene, the health council was rarely noticed and its representatives at the local scale, the county`s health delegate or the council's sub delegated or parish's agent, were showing passivity that was only awaken to declare quarantines and to announce infected ports, during the cholera outbreaks. ${ }^{67}$

The Newspaper The Lethes, published in the village of Ponte de Lima, was denouncing the lack of care and the negligence in which the cleaning of streets concerned, which seemed deposits of garbage, and of the houses which, according to the newspaper were shared by filthy animals. ${ }^{68}$ However, when cholera began to

64 Enxerga - Small straw mattress.

$65 O$ Vianense, 21 de Outubro de 1865, n.o 1140.

66 O Vianense, 3 de Fevereiro de 1866, n. ${ }^{\circ} 1183$.

67 O Vianense, 23 de Agosto de 1866, n. ${ }^{\circ} 1266$.

68 O Lethes, 15 de Agosto de 1865, n. ${ }^{\circ} 57$. 
spread in Elvas, the newspaper gives equally count of the council's administrator action, who was tireless in order to recommend to the regedores of all the villages of the council to make disappear possible focuses of infection. ${ }^{69}$

Cholera, which will return to national territory in $1884^{70}$, however without causing any victims in the Alto Minho, not only allowed some progresses in terms of the public health, but it also made possible a clear intervention from the authorities, and also of the bourgeois mentality itself, in the heart of the poorer classes, in terms of the mentalities, and lifestyle. ${ }^{71}$ The society turns to its base, moved by the philanthropic feeling, being prepared for a possible help to the poor patients of cholera, or by the fear that the disease inspires, being conscious that the poor people are the most affected, for what it was contributing, decisively, the absence of basic cares of hygiene and the habitability conditions of their houses.

Alexandra Esteves is PhD Student of Minho University. Maria Marta Lobo de Araújo is Associate Professor with aggregation of Minho University.

69 O Lethes, 31 de Outubro de 1865, n. 79.

70 On the different outbreaks of cholera consult Ferreira, F. A. Gonçalves, História da Saúde e dos Serviços de Saúde em Portugal... p. 179.

71 Consult Arnold, David, "Cholera and colonialism in British India", in Past and present, Oxford, n. ${ }^{\circ} 113,1986$, pp.119-151. 


\section{References}

Arnold, David, "Cholera and colonialism in British India" in Past and present (Oxford, n. 113, 1986), pp. 119-151.

Cascão, Rui, "Demografia e sociedade" in Mattoso, José dir., História de Portugal, vol. V (Lisboa, Círculo de Leitores, 1993), pp. 425-439.

Charlot, Monica: Marx Roland (dir.), Londres, 1851-1901. A era vitoriana ou o triunfo das desigualdades (Lisboa, Terramar, 1995).

Cyrne, Francisco, "A cólera-morbus no distrito de Viana do Castelo (Apontamentos)", Arquivo do Alto Minho, 4. vol. Tomos III e IV, (1955), pp. 106-119.

Cunha, Fanny Font Xavier da, "Evolução histórica da ciência médica e política patrimonial", Cadernos de Cultura. Medicina na Beira Interior da Pré-História ao Século XX, n. ${ }^{\circ} 16$, pp. 67-72.

Esteves, Alexandra, Assistência às vitimas de cólera no Alto Minho na primeira metade do século XIX. (in press).

Ferreira, F. A. Gonçalves, História da Saúde e dos Serviços de Saúde em Portugal (Lisboa, Fundação Calouste Gulbenkian, 1990).

Jiménez, Juab Bta Mateos. "Nacimiento de la Sanidad Internacional" Revista Española de Salud Pública, vol. 80, (2006), pp. 647-656.

Lemos, Maximiano, História da Medicina em Portugal. Doutrinas e Instituiçôes, vol. I (Lisboa, D. Quixote, 1991).

Ponce Herrero, Gabino, "Él Cólera en Alpera y Bonete. Siglo XIX.", Revista de Estúdios Albacetenses, n. ${ }^{\circ}$ 13, (1984), pp. 53-72.

Rodrigues, José Júlio. "Lisboa e o Cholera”, Biblioteca do Povo e das Escolas, n.o 88, (1884).

Roque, João Lourenço, "Epidemias no distrito de Coimbra no século XIX (18301870) in Revista Portuguesa de História, 34, (2000), pp. 1-152.

Simon Lorda e Rúa, Dominguez M., "Él cólera de 1885 en Ourense", Minius XIV, 2006, pp. 269-282.

Svobodný, Petr, "The Health of the Population and Health Policy in 19th century Bohemia: The Case of Asiatic Cholera (1830s-1900s)" in Abreu, Laurinda (ed.), European Health and Social Welfare Policies (Compostela Group of Universities and the PhoenixTN, European Thematic Network on Health and Social Welfare Policies, 2004), pp. 200-215.

Ujvari, Stefan Cunha, A História e suas Epidemias. A convivência do homem com os microrganismos, Rio de Janeiro (Editora Senac Rio, 2003).

Viegas, Valentino; Frada, João; Miguel, José Pereira. A Direç̧ão-Geral de Saúde. Notas Históricas (Lisboa, 2006).

Vigarello, Georges, O limpo e o sujo. A higiene do corpo desde a Idade Média (Lisboa, Editorial Fragmentos, 1988). 